\title{
MIDDLE LA TÈNE BRONZE FIBULAE DECORATED IN PSEUDO-FILIGREE AND PSEUDO-GRANULATION TECHNIQUES OF THE SCORDISCAN VARIANT
}

\author{
A Recognizable Feature of the Local Middle La Tène Female Costume ${ }^{1}$
}

\author{
M A R K O D I Z D A R
}

\begin{abstract}
Certain forms of bronze fibulae, alongside some forms of bronze belts, are recognizable items of the Middle La Tène Scordiscan female costume. One of those forms is the so-called Scordiscan variant of bronze fibulae with round plates decorated in pseudo-filigree and pseudo-granulation techniques. Fibulae belonging to this heterogeneous group, with specific variants singled out, are characteristic of communities along the Danube River which shared similar ideas of decoration of the female body during the Middle La Tène. The presence of numerous variants of fibulae clearly points to the existence of local workshops, regardless of noticeably the same basic decorative design concept in their production. Fibulae assigned to the Scordiscan variant have a characteristic trefoil motif with a knob on the top of the round plate and are, for now, known only from Scordiscan sites, due to which they can probably be considered products of their workshops. Finds of fibulae assigned to some other variants were also discovered at Scordiscan sites, indicating the existence of cultural contacts with neighbouring communities. In any case, bronze fibulae decorated in pseudo-filigree and pseudo-granulation techniques provide valuable findings of decorating Scordiscan women's bodies, as well as their public presentation, i.e., the fibulae probably represent a recognizable manifestation of their visual identity.
\end{abstract}

Keywords: Carpathian Basin, Middle La Tène Period, Scordisci, fibulas, female costume.

\section{INTRODUCTION}

The period of the Late Iron Age in the southeastern part of the Carpathian Basin was marked by characteristic material legacy assigned to the Scordiscan community, assumed to have arisen from the symbiosis of Celtic settlers and the local population. Within the material legacy of the Scordisci, who shared similar ritual norms with other communities of the Eastern Celts, aside from the numerous forms recorded in the Carpathian Basin, there are also certain particularities, primarily in forms belonging to female costume and jewellery. They are considered to be the contribution of the legacy of the autochthonous population and the position of the Scordisci in the south-eastern edge of the La Tène Culture. One of the influences of the autochthonous legacy is thought to be the decoration of objects in pseudo-filigree and pseudo-granulation techniques, while production of such objects by casting is considered to be the influence of the La Tène Culture (Rustoiu/Ferencz 2017, 351). It was in the area of the south-eastern Carpathian Basin during the later phase of the
Early Iron Age, where a tradition of decorating in filigree and granulation techniques existed and was adopted by the Celts and, consequently, the Scordisci (Majnarić-Pandžić 1970, 27; 2006; Szabó 1975, 148, 155; 1991, 319; 2009, 70-73; 2014, 86, 87; Szabó/Tankó 2012, 103-109). Decoration in pseudofiligree and pseudo-granulation techniques is thought to have emerged in the Transdanubian area during LTB2, as testified by Bölcske-type fibulae with such decorations, as well as certain ring jewellery items (Brezňanová 2008, 11, 12, 17; Szabó $1975,148,155)$. Distribution of the heterogeneous group of bronze Middle La Tène fibulae decorated in the techniques of pseudo-filigree and pseudogranulation, mostly recorded at sites located between Lake Balaton and the Danube River, also points to that. These fibulae have a characteristically decorated round plate on the foot, with various motifs executed in these techniques. Previous research shows that this is a recognizable part of the Middle La Tène female costume, i.e. from LTC1 (Brež̌anová 2008, 17; Bujna 2003, 95, 106). Numerous identified variants pointing to certain forms being local, i.e. produced in few workshops

\footnotetext{
1 This article was funded by the Croatian Science Foundation with the project (IP-06-2016-1749): Iron Age Female Identities in the Southern Carpathian Basin (FEMINE).
} 
(Brezñanová 2008, 16, 17), regardless of noticeably the same basic decorative design concept in their production by the Eastern Celts. One of these workshops was situated in the Scordiscan territory, as testified by finds of fibulae that manifest common characteristics in form, decoration, and technology, due to which they were identified as fibulae of the so-called Scordiscan variant. Given that these objects are gender-specific, wearing them might have indicated different aspects of the social identities of women, as well as their position within the community. Functional and decorative objects of the female costume and jewellery hold an important position in defining the characteristic material legacy of the Scordisci. Middle La Tène female costume of the Scordisci is represented by various forms of iron and bronze belts, buckles, and fibulae of different shapes. A considerable number of Middle La Tène bronze fibulae from Scordiscan sites belong to a widely distributed legacy of the La Tène Culture, pointing to existence of cultural contacts and their position in the communication network of the Carpathian Basin. On the other hand, some forms are characteristic for the Scordisci, like the somewhat later bronze fibulae of the Boljevci variant, decorated with enamel (Dizdar 2014b; 2019). One of the forms that we can consider a recognizable manifestation of Middle La Tène Scordiscan female costume is bronze fibulae decorated in the techniques of pseudo-filigree and pseudo-granulation, which were identified as the Scordiscan variant. Such fibulae, as a functional but also a decorative item, also represented an important part of the costume and visual identity of women who wore them.

\section{BRONZE FIBULAE DECORATED IN PSEUDO-FILIGREE AND PSEUDO- GRANULATION TECHNIQUES FROM THE SITES OF THE SCORDISCI}

The Middle La Tène material legacy of the Scordisci today is mostly known due to research of cemeteries and numerous chances finds also probably originating from destroyed graves, especially from the area of Syrmia and eastern Slavonia (Majnarić-Pandžić 1970; Todorović 1968; 1971; 1974). Actually, a small number of graves, primarily graves of warriors with weaponry, originate from the Middle La Tène (LTC1-C2), while only a few of preserved contemporary graves are female (Božič
1981, 318, fig. 3; Dizdar 2016, 75, 85, 86; 2018, 16; Guštin 1984, 324, fig. 13). Due to that, information about the circumstances and context of finds are missing for almost all bronze fibulae decorated in the techniques of pseudo-filigree and pseudogranulation, aside from the fibula from grave 27 from the Osijek-Zeleno polje cemetery. However, a detailed analysis of this group of fibulae from Scordiscan sites points to the emergence of a locally distributed form which probably represented an important feature of their female Middle La Tène costume. On the other hand, identifying forms with analogies in neighbouring areas might point to the direction and intensity of cultural contacts with contemporary communities, especially the ones along the Danube River, with which the Scordisci shared many common features in the development of their material legacy.

Bronze fibulae of the Middle La Tène scheme with a round plate on the foot decorated in the techniques of pseudo-filigree and pseudo-granulation, for now, represent one of the well-represented groups of fibulae at Scordiscan sites. These fibulae were first identified as variant $B$ decorated in filigree which is dated to the $1^{\text {st }} \mathrm{c}$. BC (Todorovic 1968, 53). Since they all have the same shape, aside from one from Osijek, fibulae shaped and decorated in this fashion were thought to be products of the same workshop (Majnarić-Pandžić 1970, 26). The fibulae from Osijek were dated to the latest horizon of the cemetery (Majnarić-Pandžić 1970, 39), which would correspond with LTC1 (Guštin 1984, 324, App. 1: 36). In the analysis of finds from the Scordiscan cemetery in Kupinovo, I. Drnić provides a detailed description of fibulae with round and perforated plates decorated in the techniques of pseudo-filigree and pseudo-granulation from Kupinovo, Srijemska Mitrovica, and Novi Banovci, identifying them within the local SlavonianSyrmian variant, i.e. variant BF-H1D-A from LTC1 (Drnić 2015, 79, 80).

Detailed classifications of Middle La Tène bronze fibulae with a round plate on the foot decorated in the techniques of pseudo-filigree and pseudogranulation was proposed by G. Brezñanová (2008) and A. Jovanović (2011). G. Brezňanová, with certain modifications, adopted J. Bujna's classification ${ }^{2}$ and conducted analysis of all known finds of fibulae from group BF-H1-D. Special attention was given to dimensions of the fibulae, the way the plate is connected to the foot, the motifs on the plate, the outline of the bow, and the way the spring

\footnotetext{
2 J. Bujna classified bronze fibulae decorated in the techniques of pseudo-filigree and pseudo-granulation from Slovakian sites as group BF-Hy1-D which he dated to LTC1a-b (Bujna 2003, 59, 60, 91, fig. 25; 26). G. Brezñanová left out the letter y which marks the spring with an internal chord appearing on fibulae from Slovakian sites, while in other areas, fibulae with external chords also appear, as well as the fibulae with the chord wrapped around the bow (Brezñanová 2008, 1).
} 
is shaped. Based on typological characteristics, 12 variants of fibulae $(\mathrm{A}-\mathrm{L})$ were identified. They were dated to LTC1, showed local distribution, and pointed to the position of workshops for their production. Most fibulae were recorded in the area of the Carpathian Basin, especially along the Danube River, but they appear all the way to the south-eastern Alpine region and Transylvania. Three production centres were recognized - one situated in Syrmia or the Scordiscan one, one along the Upper Sava and Drava Rivers or the Tauriscan one, and the one in the area of Transdanubia (Brezñanová 2008, 16, 17, fig. 1). The analysis showed that fibulae from Scordiscan and Tauriscan sites have larger dimensions and a plate soldered to the foot, while the fibulae from Hungarian and Slovakian sites are smaller and have plates connected to the foot by rivets (Brežnanová 2008, 11-13, 16, 17). A. Jovanović's classification is similar, conducted during the analysis of rich female cremation burial 56 from Brežice, dated to LTC1, in which a bronze fibula with a round plate decorated in pseudofiligree technique was recorded. Given the motifs on the plates, three variants were identified: - the variant from the south-eastern Alpine region has characteristic S-motifs executed in pseudo-filigree technique on the round plate. Most finds of these fibulae were discovered at sites in Slovenia. Fibulae of the Slavonian-Syrmian variant have characteristic trefoil motif on their plates executed in pseudo-filigree technique, mostly discovered at sites in Slavonia, Serbia, and southern Slovakia. Therefore, this variant includes fibulae decorated in the same motif, but the plate could have been connected by rivets or soldering. Fibulae of the Hungarian variant have a plate filled with motifs executed in techniques of pseudo-filigree and pseudo-granulation. Likewise, other forms were identified, that cannot be assigned to any of the mentioned variants (Jovanović A. 2011, 55-58, fig. 5; 6; Rustoiu 2013, 91, fig. 8). This classification of three identified variants was later used by B. Sicherl as well (Sicherl 2017, 45, fig. 11).

\section{Bronze fibulae of the Scordiscan variant}

As has been pointed out, most bronze fibulae with a round plate decorated in the techniques of pseudo-filigree and pseudo-granulation from Scordiscan sites were assigned to variant BF-H1-D-A or the so-called Scordiscan variant (Brezňanová 2008, 11, 16, 17, fig. 2: 1-5), i.e. Slavonian-Syrmian variant (Jovanović A. 2011, 57, 63, 64). The further analysis uses typological classification proposed by G. Brezňanová, with a description of all known fibulae decorated this way from Scordiscan sites, alongside which some other newly-discovered or little-known finds belonging to the so-called Scordiscan but also some other variants are depicted as well. Likewise, attention is given to some construction characteristics of the fibulae, especially to the way the plate is connected to the foot, to potentially recognize certain distribution areas which shared some technological findings in creating fibulae of this group.

Fibulae of the Scordiscan variant, representing a homogenous group of finds, have a round perforated plate on the foot. The plate is rosette-shaped and has a decoration executed in the pseudo-filigree technique along the edge. In the central part, there is a trefoil motif, i.e. three rings with a knob in the middle. Trefoil motif is usually conically protruding, although it can rarely be aligned with the edge decorated in pseudo-filigree technique. The spring has four coils with an internal chord, whereas, in some fibulae, the inner chord is wrapped around the end of the bow. The plate is soldered to the foot, while its end is connected to the bow by a clasp. The bow, most commonly, when preserved, has a trapezoidal outline and circular cross-section. Preserved fibulae are more than $5.5 \mathrm{~cm}$, i.e. between 6.5 and $7.5 \mathrm{~cm}$ long.

One of the well-preserved fibulae, that describes basic construction characteristics of fibulae of the Scordiscan variant was discovered in trench 6 at the Osijek-Zeleno polje cemetery in eastern Slavonia. According to E. Spajić, the fibula originated from a destroyed inhumation grave (Brezňanová 2008, 3, fig. 2: 1; Spajić 1954, 14, pl. V: 33; Szabó 1975, 148, fig. 1; Todorović 1968, 53, 143, pl. XVII: 5). The fibula, $7.2 \mathrm{~cm}$ long, has a low bow with a circular cross-section (Fig. 1: 1). The end of the foot is inserted in a specially made $3.3 \mathrm{~cm}$ long cast part placed above the bow with a round conically protruding plate in the middle. On one side of the plate $1.8 \mathrm{~cm}$ in diameter, there is a slightly trapezoidal broadening in which, on the bottom side, the end of the foot is inserted, while on the other side of the plate, towards a simple clasp, there are three low and narrow ribs. The bottom side of the trapezoidal broadening placed below the plate is bent downwards, making a groove in which the end of the foot is inserted and they are soldered together. That way the cast part with the round plate becomes a constituent part of the foot, which was recorded in all other fibulae of this variant. The plate's edge is decorated in the technique of pseudo-filigree, while in the centre, there is a conically protruding trefoil motif with a knob in the middle. The spring has four coils with an internal chord. 


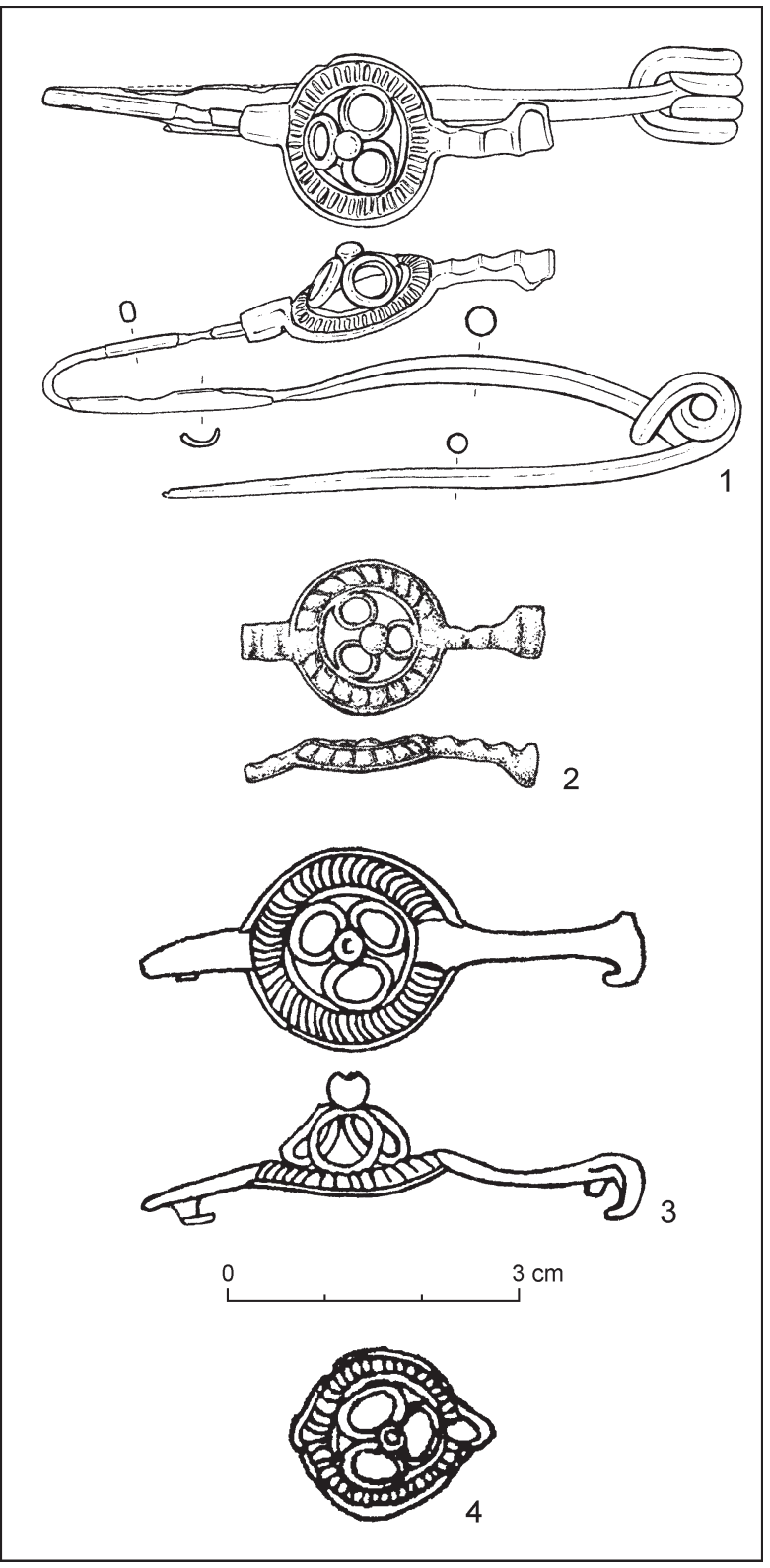

Fig. 1. Bronze fibulae of the Scordiscan variant (BF-H1D-A). 1 - Osijek-Zeleno polje, trench 6 (drawing by M. Rončević); 2 - Novi Banovci (Drnić 2015, fig. 21:3); 3 -Zemun, Danube River bank (Todorović 1971, pl. LXV: 11); 4 - Mlava valley (Stojić 2000, pl. I: 57).

Another Scordiscan cemetery, the one in Kupinovo in Syrmia, yielded two fibulae of this form. One of them is $6.8 \mathrm{~cm}$ long and has a plate with a trefoil conically protruding motif and a knob on the top (Fig. 2: 1). The part of the foot between the plate and the clasp is ribbed. The spring consists of four coils with an internal chord. The other fibula is $6.95 \mathrm{~cm}$ long and also has a spring consisting of four coils with an internal chord wrapped around the bottom part of the bow (Fig. 2: 2). The central trefoil motif with a knob is aligned with the edge of the plate. The foot is long and bent in the shape of the letter $U$. The part of the foot in front of the plate, as well as the part between the plate and the clasp, is ribbed. Both fibulae were dated to LTC1 (Brezňanová 2008, 3, fig. 2: 2, 5; Drnić 2015, 79, 153, pl. 34: 6, 7; Hunyady 1942, pl. XXI: 8; Jovanović B. 1987, 838, pl. LXXXIII: 8; Majnarić-Pandžić 1970, 26, 81, pl. IX: 3, 5; Todorović 1974, fig. 113 down). Fibula from Srijemska Mitrovica, $7 \mathrm{~cm}$ in preserved length (Fig. 2: 3), also has a conically protruding plate with a trefoil motif and a spring consisting of four coils with an internal chord which is wrapped around the bow (Brezňanová 2008, 3, fig. 2: 4; Drnić 2015, 80, fig. 21: 1; Majnarić-Pandžić 1970, 45, 88, pl. XXIII: 3). Another fibula, with a spring shaped the same way, was discovered in Srijemska Mitrovica (Fig. 2: 4). The plate has a slightly protruding trefoil motif with a knob in the middle. The bow is slightly elevated and has a circular cross-section (Drnić 2015, 80, fig. 21: 2). All of these fibulae, as well as one from Kupinovo, due to the chord wrapped around the bow, are assumed to originate from the same workshop (Breznnanová 2008, 11; Drnić 2015, 80; Majnarić-Pandžić 1970, 26). This way of shaping the spring with an internal chord wrapped around the bow was also recorded on a $5.1 \mathrm{~cm}$ long bronze fibula discovered in warrior grave 1 from Brestovik. The foot also has a round plate decorated in pseudo-granulation technique with a rosette motif, i.e. with six knobs placed along the edge of the plate and one in the middle. The spring consists of six coils. Weaponry finds date the grave to LTC1 (Popović 1994, 53, fig. 14). This way of shaping the spring with a wrapped chord is considered to represent influences from the south-eastern Alpine region (Brezňanová 2008, 11). A fragment of a foot with a plate $3.1 \mathrm{~cm}$ in preserved length discovered at the bank of the Danube River near Zemun is assigned to the fibulae of the Scordiscan variant (Fig. 1:3). Only the separately cast part with a round plate connected to the rest of the foot was preserved, as testified by the bent bottom side of the part of the foot in front of the plate. The foot was connected to the bow by a smooth clasp, while the plate was decorated with a trefoil motif and a knob in the middle; both of them conically protruding (Brezňanová 2008, 3, fig. 2: 3; Todorović 1968, 53, 154, pl. LV: 13; 1971, 143, pl. LXV: 11). This variant also includes a find of a part of a fibula from Novi Banovci, out of which also the separately cast ending part of the foot was preserved (Fig. 1: 2). In the central part of the plate there is a trefoil motif with a knob, aligned with the edge of the plate. The part between the plate and the clasp is longer and ribbed, as well as the short part placed in front of the plate (Drnić 2015, 80, fig. 21: 3). The Scordiscan variant also includes a find of a round plate discovered in the Mlava River valley 


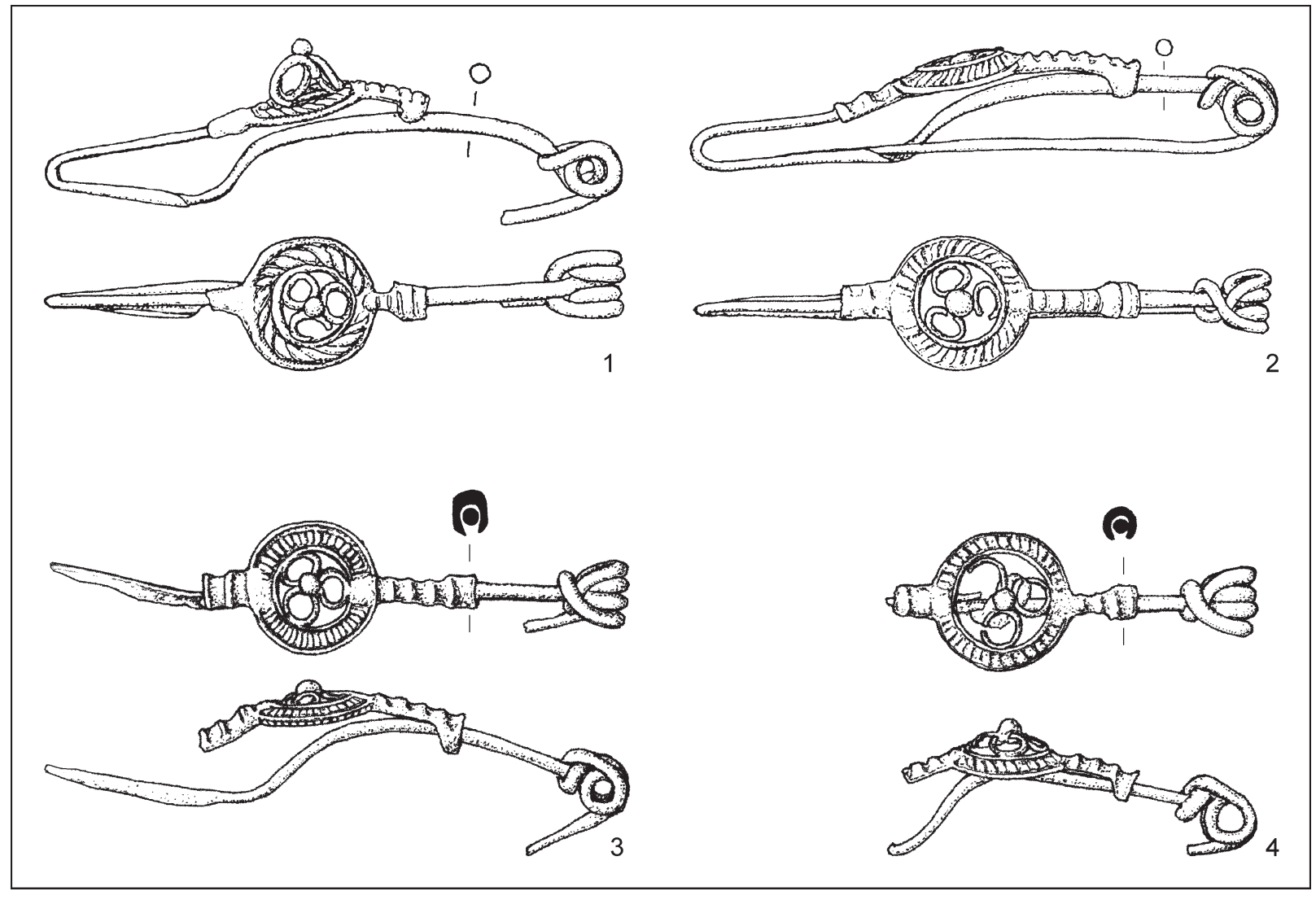

Fig. 2. Bronze fibulae of the Scordiscan variant (BF-H1D-A). 1 - Kupinovo (Drnić 2015, pl. 34: 6); 2 - Kupinovo (Drnić 2015, pl. 34: 7); 3 - Srijemska Mitrovica (Drnić 2015, fig. 21: 1); 4 - Srijemska Mitrovica (Drnić 2015, fig. 21: 2). Without scale.

(Fig. 1: 4; Stojić 2000, 62, pl. I: 57) and a part of a foot with a round plate from the settlement of Rapanović polje near Triješnica in north-eastern Bosnia. It seems that the central part with the trefoil motif and the knob, conically protruding in comparison to the edge, is also executed in pseudo-filigree technique (Kosorić 1982, 125, pl. IV: 34).

Decorating the round plate with a sequence executed in pseudo-filigree technique along the edge and with a central protruding trefoil motif with a knob on the top was also recorded in fibulae of the variant BF-H1D-K discovered in grave 425 at the Malé Kosihy cemetery and in grave 13 at the Michal nad Žitavou cemetery, which were dated to LTC1a. However, in the fibulae in question, the plate is attached to the foot by rivets (Brezñanová 2008, 3, 10, 13, fig. 3: 6, 7). ${ }^{3}$ These fibulae, considering the central motif, are thought to be Scordiscan influence, with noticeable differences in dimensions and the outline of the bow, as well as the spring consisting of six internal chords (Brezňanová 2008, 16; Drnić 2015, 80). A. Jovanović included these fibulae in the Slavonian-Syrmian variant, due to the central motif on the plate (Jovanović A. 2011, 57, 64). Find of a plate from a fibula originating from Sárbogárd is similar to the fibulae of the Scordiscan variant in the shape of the central trefoil motif. Its plate was probably damaged in cremation and was decorated with a conically protruding trefoil motif. The plate also has a decoration along its edge, making this find also similar to fibulae of the Scordiscan variant. At the top of the protruding plate seems to be a rosette motif executed in the pseudo-granulation technique. Given its central motif, M. Szabó also connects this fragment with fibulae discovered at Scordiscan sites (Szabó 1975, 148, pl. I: 8). On the other hand, fibulae of the Scordiscan variant are similar in the way their plate is soldered to the foot to the ones discovered at sites around the upper Sava and Drava Rivers and which are associated with Tauriscan workshops. The similarity is manifested in dimensions, while the difference is noticeable in the execution of the central motif on the plate (Brezňanová 2008, 5, 16, 17, fig. 2: 7-11).

\footnotetext{
3 Cremation grave 425 from the Malé Kosihy cemetery (Brež̌anová 2008, 10, fig. 3: 7; Bujna 1995, 82, pl. 40: C: 1; 2003, 59); grave
} 13 from the Michal nad Žitavou cemetery (Benadik 1961, 193, fig. 20: 6; Brezňanová 2008, 10, fig. 3: 6). 


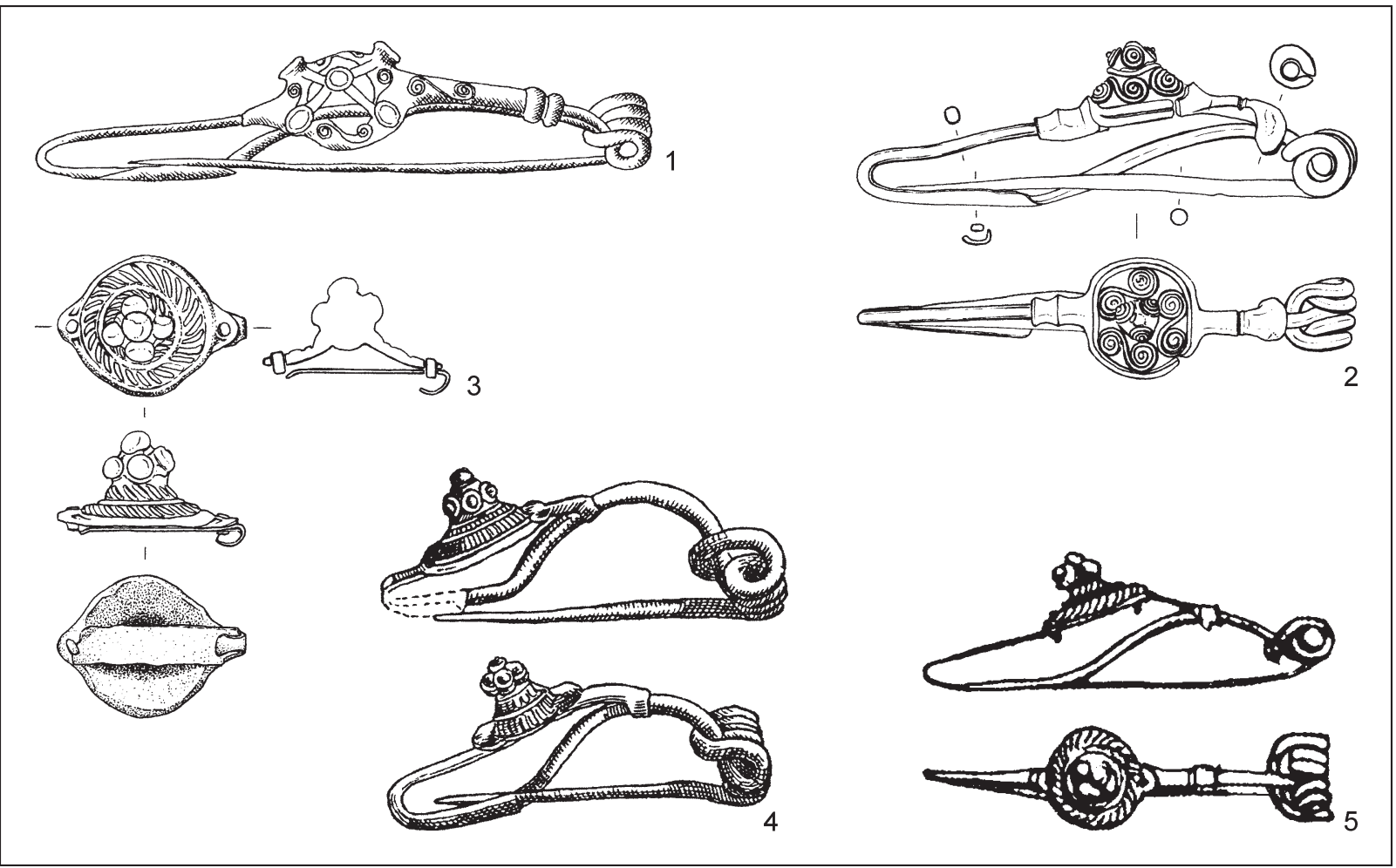

Fig. 3. Bronze fibulae of different variants. 1 - Seona-Orešac (Jovanović B. 1987, fig. 41: 5); 2 - Osijek-Zeleno polje, grave 27 (drawing by M. Rončević); 3 - Vinkovački Banovci-Šuma (drawing by M. Rončević); 4 - Apátipuszta, grave 22 (Brezňanová 2008, fig. 3: 3); 5 - Ludas-Varjú-dűlő, grave 685 (Szabó/Tankó 2012, fig. 186: 1). Without scale.

\section{Other bronze fibulae from the sites of the Scordisci}

Alongside bronze fibulae of the so-called Scordiscan variant (BF-H1D-A), finds of some other variants of fibulae with plates decorated in the aforementioned techniques were also recorded at Scordiscan sites. Find of a unique fibula, assigned to variant BF-H1D-F (Brezňanová 2008, 7, 12, fig. 2: 6), originates from the site of Seona-Orešac near Smederevo, allegedly from a destroyed inhumation grave (Todorović 1968, 28). The fibula is $11.3 \mathrm{~cm}$ long and, for now, represents one of the largest fibulae of this type known so far (Fig. 3: 1). It is one of the most lavishly decorated bronze fibulae from the Scordiscan territory which has, at the end of a long foot, a large perforated plate decorated with complex ornament. The foot and the plate are soldered together. Along the edge of the plate, on four juxtaposed spots, and in the middle, some recesses were filled with enamel. The recesses along the edge were connected to the central recess by narrow bands on which there is a decoration executed in pseudo-filigree technique. On the round edge of the plate, between the recesses, there is an S-motif also executed in the same technique. This motif also appears on the foot, right next to the plate, towards the double clasp. The low and long bow has a trapezoidal outline, while the spring consists of four internal chords (Jovanović B. 1987, 838, fig. 41: 5; Todorović 1968, 141, pl. IX: 6; 1974, pl. XVIII; Vukmanović/Radojčić 1995, 22, cat. no. 16). Alleged part of a bronze fibula from the bank of the Danube River near Zemun was also assigned to this variant, but it is probably a part of Late La Tène horse bits (Todorović 1968, 154, pl. LIV: 21; 1971, 96, pl. XLVI: 3).

Like the fibula from Seona, a unique form from Scordiscan sites is bronze fibula discovered in inhumation grave 27 at the Osijek-Zeleno polje cemetery (Spajić 1962, 40, pl. XV: 10; Szabó 1975, 148, fig. 1; Todorović 1968, 53, 143, pl. XVII: 4), assigned to variant BF-H1D-E (Brezňanová 2008, 5, 12, fig. 2: 12). The fibula is $5.8 \mathrm{~cm}$ long and has a low bow with a circular cross-section (Fig. 3: 2). The end of the long foot is soldered to a separately made cast $2.9 \mathrm{~cm}$ long part placed above the bow and has a round conically protruding plate $1.4 \mathrm{~cm}$ in diameter. In front of the plate, there is a narrow ring-shaped thickening, while towards the plate, there is a groove. A simple clasp attaches the foot to the bow near the spring. The edge of the plate is executed in two connected wires of circular cross-section. The plate is decorat- 
ed with three S-motifs executed in pseudo-filigree technique above which there is a ring made of narrow wire with a hemispherical hollow protrusion executed in the shape of three smaller springs also made in the same technique. The spring consists of four coils with internal chord.

Two bronze Early La Tène fibulae of the Karaburma 63 type with massive bows decorated with an oval decoration, i.e. almond motif, are also mentioned as finds from grave 27. Chains hang from fibula's springs (Spajić 1962, 39, 40, pl. XIV: 8; XV: 9). These fibulae represent a local variant of Duchovtype fibulae from LTB2 (Božič 1981, 317, pl. 1: 15; 6: 3; 11: 4; Drnić 2015, 76). Detailed analysis revealed they belong to variant c of this type of fibula (Marić 2015, 151, 152). Among jewellery also discovered in the grave are a fragment of a two-part bronze bracelet of the Osijek type (Spajić 1962, 40, pl. XV: 11) dated to LTC1 (Božič 1981, 319, pl. 2: 28; 11: 12) and a fragment of a sapropelite bracelet with an oval cross-section (Spajić 1962, 40). Given the different periods to which the fibulae and the Osijek-type bracelet are dated, these are probably finds from two destroyed female graves, one of which belonged to LTB2, and the other to LTC1. This is confirmed by the fact that the finds were handed over to the museum by workers, i.e. they were not discovered in grave assemblages, which once again testifies to part of graves published by E. Spajić not being reliable (Dizdar 2014a, 190; 2018, 25-27). In any case, the later assumed grave would probably include the bronze fibulae decorated in pseudo-filigree technique and a fragment of the Osijek-type bronze bracelet.

The mentioned fibula of the BF-H1D-E variant from grave 27 (Brezňanová 2008, 5, 12, fig. 2: 12) for now represents a single find of this variant. Conically protruding plate and rosette motif on its top make it similar to the fibulae of variants BF-H1D-G and BF-H1D-I discovered at sites in western Hungary (Brezñanová 2008, 9, 12, 13, fig. 3: 1, 3, 4), rather than to the fibula of the Scordiscan variant discovered at the cemetery in Osijek. This is no surprise, considering the position of the Osijek cemetery on the Drava River and its already documented connection to sites in western Hungary (Dizdar 2018, 25). Nevertheless, this fibula is connected to Scordiscan variant fibulae in the way the foot is joined to the round plate, i.e. the soldered joint. On the other hand, based on the way the plate is decorated in S-motifs, G. Brezňanová connects this fibula to variant $B$ recorded at sites at the upper Sava and Drava Rivers, i.e. it is assumed that they were imported from the Tauriscan territory (Brezñanová 2008, 5, 11, 12).
Find of decorated round plate from a fibula's foot discovered at the site of Vinkovački Banovci-Šuma situated east of Vinkovci can also be assigned to variant BF-H1D-I (Brezňanová 2008, 9, 12, 13, fig. 3: 3, 4). The fragment was discovered during the field survey conducted in spring 2019. ${ }^{4}$ Only the conically protruding plate which was situated on the foot was preserved (Fig. 3: 3). The plate, $1.6 \mathrm{~cm}$ in diameter, has an edge decorated with a double sequence of pseudo-filigree decoration, while in the top part, there is a rosette motif executed in four knobs and another knob on the very top. One smaller semi-oval protrusion with a rivet attached to a narrow band-shaped plate placed on the bottom side of the round plate is placed on each of the two juxtaposed sides of the plate. The fragment of this fibula differs in the way the plate attaches to the foot from the fibulae of the Scordiscan variant, i.e. this is, for now, the only known find of this type of attaching of the plate in the Scordiscan territory.

The round plate of the fibula from Vinkovački Banovci, in the way it is decorated and its plate is attached to the foot, corresponds to fibulae discovered in western Hungary which were identified as variant BF-H1D-I and which are assumed to be products of the same workshop. It is emphasized that the fibulae of this variant have, aside from the way the plate is attached to the foot by rivets, a characteristic conically protruding plate with a double sequence executed in pseudo-filigree technique along the edge, while on the top there is a rosette motif executed in the technique of pseudo-granulation - four knobs on the side and one on the top. Likewise, the fibulae of this variant have a shorter and higher bow with a semi-circular outline, a short foot, and a spring made of six coils with an internal chord (Brezñanová 2008, 9, 13, fig. 3: 3, 4). Two fibulae of this variant were discovered in grave 22 at the Apátipuszta cemetery (Fig. 3: 4; Wosinsky 1896, 567, 568, pl. CXLIII: 6, 7), while one was discovered at the Rácalmás-Kulcs cemetery and has a profiled clasp connecting to the middle of the bow (Szabó 1975, 148, pl. I: 6, 7). Fibula from cremation grave 685 at the Ludas-Varjú-dülő cemetery in which an adult woman was buried can also be assigned to variant BF-H1D-I. The grave was dated to horizon 6, i.e. LTC1. The fibula is $5.1 \mathrm{~cm}$ long and assigned to type BF-Hy1-Aa-D in J. Bujna's classification. On a somewhat longer foot, there is a round plate which on the conically protruding central part have four knobs and another on the top (Fig. 3: 5). Two rivets attach the plate to the foot. The spring consists of six coils with an internal chord (Szabó/Tankó 2006, 333,

\footnotetext{
4 I would like to thank my colleagues Hrvoje Vulić and Boris Kratofil from the Municipal Museum in Vinkovci for the finds collected at the Vinkovački Banovci-Šuma site.
} 
fig. 6: 1; 2012, 28, 94, 95, 142, fig. 150; 186: 1; pl. X: 5). It is pointed out that the fibula's shape was recorded in the Eastern Celts in the area of the Carpathian Basin (Szabó/Tankó 2012, 95).

Pair of fibulae from the Sárbogárd-Szecsőd cemetery assigned to variant BF-H1D-G (Brezňanová 2008, 7, 9, fig. 3:1) is similar to the mentioned fibulae of the BF-H1D-I variant. The plate's bottom part is decorated with four concentric pseudo-filigree sequences, while the upper part has four knobs and another on the top. The spring consists of six coils with an internal chord (Szabó 1975, 147, pl. I: 4, 5). The already mentioned deformed fragment of a decorated plate with a trefoil motif damaged in cremation originates from the same site, probably a grave (Szabó 1975, 148, pl. I: 8). Two fibulae worn in pair were discovered in cremation grave 87/167 at the Sajópetri-Homoki-szőlőskert cemetery are also close to variant BF-H1D-I. A woman between the age of 15 and 18 was buried in the grave, whose costume, aside from an iron belt, all together included nine bronze and iron fibulae. The grave was dated to horizon 6, i.e. LTC1. Fibulae are 4.2 and $4.5 \mathrm{~cm}$ long, one of them damaged, probably in cremation. The plate of one of the fibulae has the lower half decorated with two sequences of densely placed smaller knobs, while on the to there is one larger knob. The plate of another fibula has only one sequence of sparsely placed knobs along the edge and a larger knob on the top as well. The fibulae have the springs consist of four coils with an external chord (Szabó/Tankó 2018, 126, 143, 144, fig. 112; pl. LVIII: 8, 9).

There is a rosette motif on the top of the plate of fibulae of two more variants also recorded at sites in western Hungary, with the difference in the number of concentric circles executed in pseudo-filigree technique in the bottom part of the plate. Fibula from grave 2 from the Aba-Belsőbáránd cemetery dated to LTC1a, was assigned to variant BF-H1D-H. The fibula has a plate decorated with seven pseudofiligree concentric sequences, one of which is wider. The top had a rosette motif. Spring consists of six coils with an external chord (Brezñanová 2008, 9, fig. 3: 2; Petres 1971, 139, fig. 3; Szabó 1975, 147, pl. I: 2, 3). Fibulae from the Jutas cemetery are also assigned to this variant (Brezňanová 2008, 9; Hunyady 1942, pl. XXI: 9). The BF-H1D-J variant 5.5. cm long fibula from grave 2 at the Szob cemetery is similar. The fibula has a plate with four pseudo-filigree concentric sequences, while on the top, there is a rosette motif composed of four small knobs. The spring has five coils with an external chord (Brezňanová 2008, 10, 13, fig. 3: 5; Horváth 1945, 62, fig. 2: 1; Tankó 2014, 264,265 , fig. 6). The round plate is placed above the bow and it seems to be separately cast and soldered to the long foot, similarly to the plates of the Scordiscan and Tauriscan variants (Brezňanová 2008, 10, 13).

The mentioned comparisons for the find of the plate from Vinkovački Banovci show that it was probably a part of a BF-H1D-I variant fibula which, as well as fibulae of some other variants (BF-H1D-G, $-\mathrm{H}$ ), is assumed to have been produced in workshops situated in the area of western Hungary. Common characteristics, aside from smaller dimensions, are the way the plate connects to the foot and the plate decorated with a rosette motif in the middle (Brezñanová 2008, 9, 17, fig. 3: 1-5). Due to that, the fragment of the fibula from Vinkovački Banovci can probably be considered proof of established cultural contacts between the area of eastern Slavonia and western Syrmia with western Hungary during the Middle La Tène, as shown by some other types of finds (Dizdar 2014a, 190; 2016, 86; 2018, 25-27).

\section{CONCLUSION}

Bronze fibulae with a round plate on the foot decorated in the techniques of pseudo-filigree and pseudo-granulation are a recognizable form of the Middle La Tène female costume of the Scordisci. They are fibulae of the so-called Scordiscan variant (BF-H1D-A) representing local style (Fig. 4) of a widely distributed form of Middle La Tène fibulae which was produced according to the decorative concept of the Eastern Celts and which is perhaps best recognized in characteristic forms of female costume (Hauschild 2010, 173). Actually, the mentioned regionalization recognized during the Middle La Tène is especially visible in female costume - in characteristic forms of belts and fibulae, as well as some items of ring jewellery (Dizdar 2016; 2018). Fibulae of the Scordiscan variant have plates decorated with a trefoil motif executed in repoussé technique with a knob in the middle. Their characteristics are larger dimensions and the plate soldered to the foot. Although none of the fibulae from Scordiscan sites originate from closed grave assemblages, they can probably be dated to LTC1 when fibulae of this heterogeneous group from the sites in the Carpathian Basin are dated (Brezňanová 2008, 19; Bujna 2003, 95, 106). Therefore, this is a group of fibulae with various variants identified, which were mostly recorded at sites along the Danube River and to the moth of the Sava River, but are known all the way to the south-eastern Alpine region. Three basic production centres were identified, each with characteristic forms recognized based on the combination of morphological and technological characteristics of fibulae (Brezňanová 2008; Jovanović A. 2011). The distribution of certain 


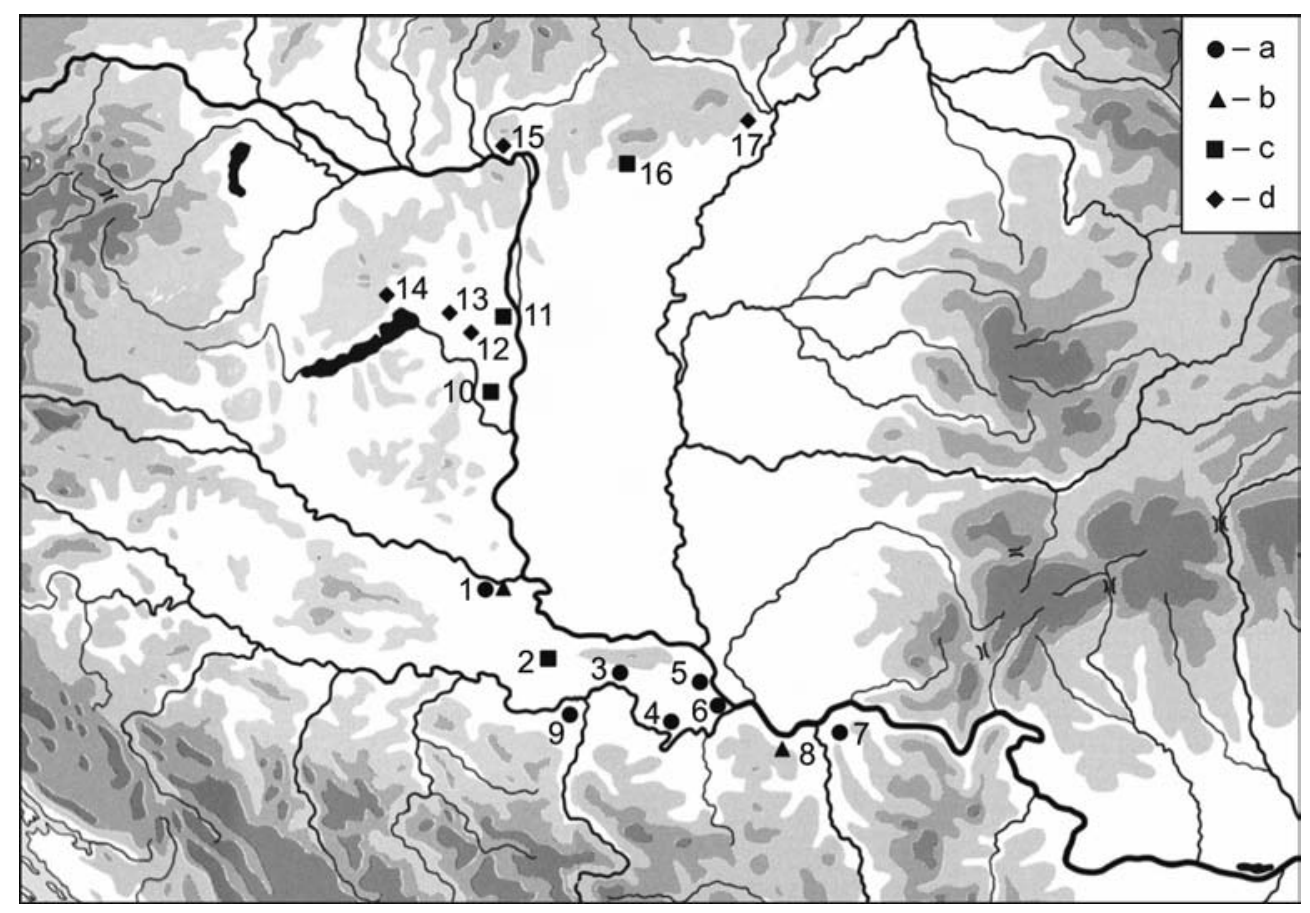

Fig. 4 Distribution of fibulae decorated in pseudo-filigree and pseudo-granulation techniques. Caption: a - fibulae of the Scordiscan variant (BF-H1D-A); b - fibulae of other variants from the Scordiscan sites (BF-H1-D-E and -F); c - fibulae of the BF-H1D-I variant; $\mathrm{d}$ - fibulae of other Transdanubian variants (BF-H1D-G, -H and -J). 1 - Osijek-Zeleno polje; 2 - Vinkovački Banovci-Šuma; 3 - Srijemska Mitrovica; 4 - Kupinovo; 5 - Novi Banovci; 6 - Zemun; 7 - Mlava River valley; 8 - Seona-Orešac; 9 - Triješnica-Rapanović polje; 10 - Apátipuszta; 11 - Rácalmás-Kulcs; 12 - Sárbogárd-Szecsőd; 13 - Aba-Belsőbáránd; 14 - Jutas; 15 - Szob; 16 - Ludas-Varjú-dűlő; 17 - Sajópetri-Homoki-szőlőskert.

variants, including the Scordiscan variant (Fig. 4), points to the position of workshops for their production (Brezñanová 2008, 16, 17). The recognizable characteristics of the fibulae of the Scordiscan variant in comparison to other variants point to their origin in workshops that were situated in their territory and produced items according to widely accepted ideas.

On the other hand, the find of the round plate from the foot of the fibulae from Vinkovački Banovci has direct comparison with fibulae of the BF-H1D-I variant recorded in the area of Hungary (Fig. 4). They correspond in the way they were produced, i.e. the way their plate is connected to the foot by rivets and the way the rosette motif is executed in pseudo-granulation technique. If we assume that this fragment originates from a destroyed grave, it is possible that the fibula was integrated into the local Middle La Tène female costume. Likewise, this find probably represents a proof of cultural transfer through communication which followed the course of the Danube River and which was already documented for certain Middle La Tène forms of female costume and jewellery (Dizdar 2016, 86; 2018, 25-27). Moreover, a similar direction of contacts is indicated by somewhat older fibulae of the Bölcske type from LTB2, one of which was discovered in
Vukovar, whose decoration techniques, as well as motifs, probably represent a conceptual paradigm for the creation of Middle La Tène forms of fibulae (Brezňanová 2008, 12, 17; Majnarić-Pandžić 2007, 801; Szabó 1975, 149-151, 155). Actually, fibulae of the Bölcske type also show higher distribution along the Danube (Rustoiu 2008, 118, fig. 58; 2009, 7, fig. 1). The opposite direction of cultural contacts is considered to be reflected by fibulae of the variant BF-H1D-K recorded at sites in south-western Slovakia. These fibulae are also decorated with a trefoil motif with a knob in the middle, due to which is assumed that they were probably created under the influences from the south of the Carpathian Basin (Brezñanová 2008, 16). Actually, it was always thought that it was the Celts coming to the south-eastern part of the Carpathian Basin, and consequently, the Scordisci, who transferred knowledge about the decoration in filigree and granulation techniques towards the northern parts of the Carpathian Basin (MajnarićPandžić 1970, 27; 2006; Szabó 1975, 148, 155; 1991, 319; 2009, 70-73; 2014, 86, 87; Szabó/Tankó 2012, 103-109). Production of items with such decoration by casting is considered to be the influence of the La Tène Culture (Rustoiu/Ferencz 2017, 351). The creation of this way of decorating is found in Transdanubia 
during LTB2, as testified by the mentioned fibulae of the Bölcske type, as well as items of ring jewellery decorated in this fashion (Brezñanová 2008, 11, 12).

Middle La Tène female costume of the Scordisci, although only a small number of graves is preserved, is today well-known thanks to numerous finds originating from destroyed cemeteries in Symia and eastern Slavonia (Majnarić-Pandžić 1970; Todorović 1968; 1971). Fibulae of the Scordiscan variant decorated in the techniques of pseudo-filigree and pseudo-granulation are a recognizable group of finds. Almost canonically executed central motif and the same technological principle of their production indicates that this is an important part of their costume, alongside some other forms of bronze belts and fibulae. Such objects testify to the emergence of a recognizable visual code that could be used to express certain social or gender identities, while female costume probably also had an important symbolical role in social communication. Actually, some details of female costume could signify that its owner belongs to a certain community within a wider cultural landscape. The fibulae of the Scordiscan variant could be a good example since they have a unique form that was produced according to a widely-accepted concept of decoration. On the other hand, the existence of numerous variants produced according to a similar paradigm indicates that certain communities that are ethnically and/ or culturally different, but have close contacts and share a common way of life, could create a costume of similar functional structure (Rustoiu/Uruştiu 2013,
$77,78)$. Therefore, this is one recognizable regional form of the Middle La Tène female costume, characteristic of communities situated along the Danube which shared similar ideas of decoration of women's bodies. These fibulae represented a recognizable external expression of a defined visual code and identity of women in Danube region. Wearing them, as a part of the complex decoration of woman's bodies, was probably important in creating an idealized image of their wearers and their social status. Likewise, it needs to be pointed out that areas of distribution of various variants of fibulae partly overlap (Fig. 4), which might point to the possibility of certain workshops producing fibulae of different forms, with personal selectivity potentially playing an important role. Finds of certain fibulae outside of their basic area of distribution, such as the fragment from Vinkovački Banovci, could point to the mobility of women who wore such fibulae or the craftsmen who produced them. But, likewise, these could have been objects of cultural transfers, used for exchanging ideas and knowledge necessary for the production of such complex objects. Due to that, these fibulae, as functional, but also decorative elements, probably represented an important part of the costume and visual identity of women who wore them, i.e. they testify to the way bodies of Scordiscan women were decorated and publicly presented. My esteemed colleague Karol Pieta dedicated a part of his abundant scholarly opus to the Middle La Tène female costume and jewellery items. We wish him many more such papers.

\section{BIBLIOGRAPHY}

Benadik 1961 - B. Benadik: Grafitova keramika v laténskych hroboch na Slovensku. Slovenská archeológia 9, 1961, 175-208.

Božič 1981 - D. Božič: Relativna kronologija mlajše železne dobi v jugoslovenskem Podonavju. Arheološki vestnik 32, 1981, 315-336.

Brezňanová 2008 - G. Brezňanová: Príspevok k jednému z typov stredolaténskych spôn. Slovenská archeológia 56, 2008, 1-20.

Bujna 1995 - J. Bujna: Malé Kosihy. Latènezeitliches Gräberfeld. Katalog. Archaeologiae Slovaca Monographiae. Catalogi 7. Nitra 1995

Bujna 2003 - J. Bujna: Spony z keltských hrobov bez výzbroje z územia Slovenska. (Typovo-chronologické triedenie LTB- a C1-spôn.) Slovenská archeológia 51, 2003, 39-108.

Dizdar 2014a-M. Dizdar: Bronze Belt from Osijek-Evidence of Contacts of the Scordisci with Central Europe and Manching During the Middle La Tène? In: M. Guštin/ W. David (eds.): The Clash of Cultures? The Celts and the Macedonian World. Schriften des Kelten Römer Museums Manching 9. Manching 2014, 189-200, in press. Online available at: https://pdfcookie.com/documents/gutin- m-david-w-eds-the-clash-of-cultures-the-celts-andthe-macedonian-world-manching-2014-in-printex2040jw6pl3

Dizdar 2014b-M. Dizdar: Bronze Fibulae with Enamel Inlay from Scordiscan Sites. In: S. Berecki (ed.): Iron Age Crafts and Craftsmen in the Carpathian Basin. Proceedings of the International Colloquium from Târgu Mureș, 10-13 October 2013. Bibliotheca Mvsei Marisiensis. Series Archaeologica 7. Cluj-Napoca 2014, 97-114.

Dizdar 2016 - M. Dizdar: Middle La Tène Female Iron Belts in the south-eastern part of the Carpathian Basin - is it Something Local and/or Global? In: S. Berecki (ed.): Iron Age Chronology in the Carpathian Basin. Proceedings of the International Colloquium from Târgu Mureş, 8-10 October 2015. Bibliotheca Mvsei Marisiensis. Series Archaeologica 12. Cluj-Napoca 2016, 75-96.

Dizdar 2018 - M. Dizdar: Reflections about Some Specific Finds of Female Costume in the Southern Carpathian Basin-Can We Recognize Female Mobility in the Middle La Tène? In: S. Berecki/A. Rustoiu/M. Egri (eds.): Iron Age Connectivity in the Carpathian Basin. Proceedings of the International Colloquium from Târgu Mureş, 13-15 October 2017. 
Bibliotheca Mvsei Marisiensis. Series Archaeologica 16. Cluj-Napoca 2018, 15-38.

Dizdar 2019 - M. Dizdar: New finds of bronze fibulae with enamel - what women liked to wear during the Middle and Late La Tène in the southern Carpathian Basin. In: N. Beljak Pažinová/D. Repka (red.): Sedem kruhov Jozefa Bujnu. Studia Historica Nitriensia 23. Supplementum 2. Nitra 2019, 33-47.

DOI: https://doi.org/10.17846/SHN.2019.23.S.33-47

Drnić 2015 - I. Drnić: Kupinovo. Groblje latenske kulture Kupinovo. A La Tène Culture Cemetery. Katalozi i monografije 12. Zagreb 2015.

Guštin 1984 - M. Guštin: Die Kelten in Jugoslawien. Jahrbuch des Römisch-Germanischen Zentralmuseums Mainz 31, 1984, 305-363.

DOI: https://doi.org/10.11588/jrgzm.1984.0.58782

Hauschild 2010 - M. Hauschild: 'Celticised' or 'Asimilated'? In search of foreign and indigenous people at the time of the Celtic Migrations. In: S. Berecki (ed.): Iron Age Communities in the Carpathian Basin. Proceedings of the International Colloquiums from Târgu Mureş, 9-11 October 2009. Bibliotheca Mvsei Marisiensis Seria Archaeologica II. Cluj-Napoca 2010, 171-180.

Horváth 1945 - J. A. Horváth: A Szobi kelta temető. Folia Archaeologica 5, 1945, 60-65.

Hunyady 1942 - I. Hunyady: Kelták a Kárpátmedencében, Táblakötet. Dissertationes Pannonicae. Ser. II. Fasc. 18. Budapest 1942.

Jovanović A. 2011 - A. Jovanović: Middle La Tène female grave 56 from Brežice, Slovenia. In: M. Guštin/M. Jevtić (eds.): The Eastern Celts. The Communities between the Alps and the Black Sea. Annales Mediterranei. KoperBeograd 2011, 51-64.

Jovanović B. 1987 - B. Jovanović: Istočna grupa. In: A. Benac (ed.): Praistorija jugoslavenskih zemalja V. Željezno doba. Sarajevo 1987, 815-854.

Kosorić 1982 - M. Kosorić: Rezultati istraživanja praistorijskih naselja na području Semberije. Članci i građa za kulturnu istoriju istočne Bosne 14, 1982, 121-132.

Majnarić-Pandžić 1970 - N. Majnarić-Pandžić: Keltsko-latenska kultura u Slavoniji i Srijemu. Acta Musei Cibalensis 2. Vinkovci 1970.

Majnarić-Pandžić 2006 - N. Majnarić-Pandžić: Balkan Jewellery Production Techniques In Iron Age Pannonia. Folia Archaeologica Balkanica I. In Honorem Verae Bitrakova Grozdanova. Skopje 2006, 129-143.

Majnarić-Pandžić 2007 - N. Majnarić-Pandžić: Brončani srednjolatenski nakit iz Vukovara ukrašen plastičnim i pseudofiligranskim stilom. In: M. Blečić/M. Črešnar/ B. Hänsel/A. Hellmuth/E. Kaiser/C. Metzner-Nebelsick (ur. - Hrsg. - eds.): Scripta Praehistorica in honorem Biba Teržan. Situla 44. Ljubljana 2007, 797-811.

Marić 2015 - A. Marić: Nova interpretacija groba sa skeletnim ukopom žene iz mlađeg željeznog doba s Kamenjače u Brezi kod Sarajeva. Godišnjak Centar za balkanološka ispitivanja 44, 2015, 143-157.

Petres 1971 - E. F. Petres: A Kelták Fejér Megyében. Fejér Megye Története I/3. Székesfehérvár 1971.

Popović 1994 - P. Popović: Latenski nalazi iz Brestovika. Zbornik narodnog muzeja 15/1, 1994, 51-56.

Rustoiu 2008 - A. Rustoiu: Războinici şi societate în aria celtică Transilvăneană. Studii pe marginea mormântului cu coif de la Ciumeşti. Interferențe etnice şi culturale în milenile I a. Chr.-I p. Chr. 13. Cluj-Napoca 2008.
Rustoiu 2009 - A. Rustoiu: Masters of metals in the Carpathian basin (workshops, production centres and funerary manifestations in the early and middle La Tène). Ephemeris Napocensis 19, 2009, 7-21.

Rustoiu 2013 - A. Rustoiu: A. Double Costumes in Female Burials from the Carpathian Basin. Comments Regarding Some Garment Assemblages from Fântânele (Romania) and Brežice (Slovenia). In: I. V. Ferencz/N. C. Rişcuța/O. T. Bărbat (eds.): Archaeological Small Finds and Their Significance. Proceedings of the Symposium: Costume as an Identity Expression. Cluj-Napoca 2013, 89-100.

Rustoiu/Ferencz 2017 - A. Rustoiu/I. V. Ferencz: Cross-cultural connections between the Middle and Lower Danube Regions during the Late Iron Age. Archäologisches Korrespondenzblatt 47, 2017, 341-357.

Rustoiu/Urusțiu 2013 - A. Rustoiu/A. Urusţiu: Indigenous and Celtic Garment Assemblages in Banat and the Surrounding Areas at the Beginning of the La Tène Period (Observations Regarding the Silver Spiral Earrings). In: I. V. Ferencz/N. C. Rişcuța/O. T. Bărbat (eds.): Archaeological Small Finds and Their Significance. Proceedings of the Symposium: Costume as an Identity Expression. Cluj-Napoca 2013, 77-88.

Sicherl 2017 - B. Sicherl: Ein Neufund einer Fibel des Typs Benstrup aus Anreppen, Kreis Paderborn. Zu den Kulturbeziehungen zwischen dem Maasgebiet und Nordwestdeutschland zu Beginn der späten Eisenzeit. Archäologie in Ostwestfalen 13, 2017, 37-49.

Spajić 1954 - E. Spajić: Nalazište mlađeg željeznog doba s terena Osijeka. Osječki zbornik 4, 1954, 7-18.

Spajić 1962 - E. Spajić: Nalazište mlađeg željeznog doba s terena Osijeka. Osječki zbornik 8, 1962, 37-55.

Stojić 2000 - M. Stojić: Najnoviji slučajni nalazi fibula iz gvozdenog doba u dolini Mlave. Viminaciom 11, 2000, 57-67.

Szabó 1975 - M. Szabó: Sur la Question du Filigrane dans l'Art des Celtes Orientaux. Alba Regia 14, 1975, 144-165.

Szabó 1991 - M. Szabó: The Celts and Their Movements in the Third Century B.C. In: The Celts. Exibition Catalogue. Milano 1991, 303-320.

Szabó 2009 - M. Szabó: L'art du pseudo-filigrane. Une technique des peuples celtiques d'Europe centrale. Dossiers d'Archeologie 335, 2009, 68-73.

Szabó 2014 - M. Szabó: Sur la question de l'elite des celtes orientaux a l'Age du Fer. Acta Archaeologia Academiae Scientiarum Hungaricae 65, 2014, 73-117.

DOI: https://doi.org/10.1556/AArch.65.2014.1.3

Szabó/Tankó 2006 - M. Szabó/K. Tankó: Nécropole laténienne à Ludas-Varjú-dűlő. Acta Archaeologia Academiae Scientiarum Hungaricae 57, 2006, 325-343.

DOI: https://doi.org/10.1556/aarch.57.2006.4.2

Szabó/Tankó/ 2012 - M. Szabó/K. Tankó: La nécropole celtique à Ludas-Varjú-dűlő. In: M. Szabó (dir.): La nécropole celtique à Ludas-Varjú-dúlő. Budapest 2012, 9-152.

Szabó/Tankó 2018-M. Szabó/K. Tankó: La nécropole celtique à Sajópetri-Homoki-Szőlőskert. In: M. Szabó (dir.): La nécropole celtique à Sajópetri-Homoki-Szölőskert. Paris 2018, 9-222.

Tankó 2014 - K. Tankó: The graves of Szob and some southern aspects of La Tène finds from northern Hungary. In: M. Guštin/W. David (eds.): The Clash of Cultures? The Celts and the Macedonian World. Schriften des Kelten Römer Museums Manching 9. Manching 2015, 259-267, in press. Online availale at: https://pdfcookie.com/documents/gutin-m-david-w-eds-the-clash-of-cultures-the- 
celts-and-the-macedonian-world-manching-2014-inprint-ex2040jw6pl3

Todorović 1968 - J. Todorović: Kelti u jugoistočnoj Evropi. Dissertationes et Monographiae 7. Beograd 1968.

Todorović 1971 - J. Todorović: Katalog praistorijskih metalnih predmeta. Serija zbirke i legati Muzeja grada Beograda 3. Beograd 1971.

Manuscript accepted 1. 7. 2021

Translated by Kristina Deskar
Todorović 1974 - J. Todorović: Skordisci. Monumenta Archaeologica 2. Novi Sad - Beograd 1974.

Vukmanović/Radović 1995 - M. Vukmanović/N. Radović: Katalog metala II. Praistorija 3. Beograd 1995.

Wosinsky 1896 - M. Wosinsky: Tolnavármegye. Az öskortól a honfoglalásig. Tolnavármegye története. Budapest 1896.

Dr. sc. Marko Dizdar Institute of Archaeology Jurjevska ulica 15 HR - 10000 Zagreb marko.dizdar@iarh.hr 